
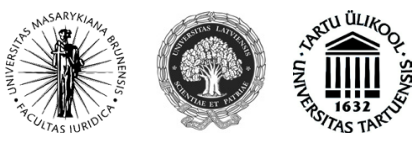

ISSN 1392-6195 (print) ISSN 2029-2058 (online) JURISPRUDENCIJA JURISPRUDENCE 2014, 21(2), p. 421-439.

\title{
KAIP LIETUVOJE ATSIRADO PIRMASIS KONSTITUCINIS İSTATYMAS
}

\author{
Vytautas Sinkevičius \\ Mykolo Romerio universiteto Teisès fakulteto \\ Konstitucinès ir administracinès teisès institutas \\ Ateities g. 20, LT-08303 Vilnius, Lietuva \\ Tel.: (+370 5) 2714546 \\ Elektroninis paštas: v.sinkevicius@mruni.eu
}

Pateikta 2014 m. sausio 21 d., parengta spausdinti 2014 m. gegužès 30 d.

doi:10.13165/JUR-14-21-2-05

\section{Ivadas}

Lietuvos Respublikos Aukščiausioji Taryba 1991 m. vasario 11 d. priėmė Konstitucinị ịstatymą „Dèl Lietuvos valstybės“. Tai pirmasis konstitucinis ịstatymas Lietuvos teisès istorijoje, iki tol konstitucinių i̇statymų Lietuvos teisės sistemoje nebuvo. Teisès mokslinèje literatūroje nẻra nagrinèta, kodèl reikèjo priimti ši konstitucinị istatymą. Straipsnyje atskleidžiamos konstitucinio įstatymo „Dèl Lietuvos valstybès“ prièmimo aplinkybės, jo ryšys su $1991 \mathrm{~m}$. vasario 9 d. įvykusia gyventojų visuotine apklausa (plebiscitu). Nagrinejama, kuo nurodytas konstitucinis įstatymas skiriasi nuo šiuo metu galiojančioje Konstitucijoje ịtvirtintų konstitucinių ịstatymų instituto. Konstitucinio įstatymo „Dèl Lietuvos valstybès“ prièmimo aplinkybių tyrinėjimai gali padèti geriau suprasti, kaip Lietuvoje atsirado konstituciniai įstatymai, kokia yra jų paskirtis, teisine galia, taip pat gali atskleisti kai kuriuos iki šiol mažai žinomus Lietuvos valstybingumo įtvirtinimo aspektus. Straipsnio autorius tiesiogiai dalyvavo

Jurisprudencija/Jurisprudence

(C) Mykolo Romerio universitetas, 2014

(C) Mykolas Romeris University, 2014
ISSN 1392-6195 (print), ISSN 2029-2058 (online) http://www.mruni.eu/lt/mokslo_darbai/jurisprudencija/ http://www.mruni.eu/en/mokslo_darbai/jurisprudencija/ 
rengiant $1991 \mathrm{~m}$. vasario $11 \mathrm{~d}$. konstitucinį ịstatymą „Dèl Lietuvos valstybès“, yra išsaugojęs kai kuriuos tuo laikotarpiu darytus užrašus, todèl straipsnyje remiamasi ne tik tuomet galiojusiu Laikinuoju Pagrindiniu İstatymu ir kitais teisès aktais, bet ir autentiška, iki šiol niekur neskelbta medžiaga.

\section{Konstitucinio įstatymo „Dèl Lietuvos valstybès“ prièmimo aplinkybès}

$1991 \mathrm{~m}$. vasario 9 d. Lietuvoje įvyko gyventojų visuotinė apklausa (plebiscitas), kurios metu 3/4 Lietuvos piliečių, turinčių rinkimų teisę, pasisakè už tai, kad jie pritaria rengiamos naujos Konstitucijos teiginiui „Lietuvos valstybė yra nepriklausoma demokratinè respublika“. Visuotinè gyventojų apklausa (plebiscitas) buvo surengta kaip „atsakymas ị Tarybų Sąjungos vadovybès organizuojamą referendumą dèl TSRS išlikimo, kuris turèjo ịvykti $1991 \mathrm{~m}$. kovo 17 d.“" Lietuvos pozicija dèl Sovietų Sąjungos organizuojamo referendumo buvo vienareikšmè: nuo 1990 m. kovo 11 d., kai buvo atkurta nepriklausoma Lietuvos valstybė, jokie Sovietų Sąjungos įstatymai Lietuvoje neveikia, todèl Sovietų Sąjungos mėginimas organizuoti referendumą ir Lietuvoje yra šiurkštus ir neleistinas Sovietų Sąungos kišimasis ị Lietuvos Respublikos vidaus reikalus ir naujas pasikėsinimas ị jos suverenitetą. $1991 \mathrm{~m}$. sausio $13 \mathrm{~d}$. Sovietų Sąjunga ịvykdè prieš Lietuvos Respubliką karinę agresiją, kurios metu žuvo 14 Lietuvos piliečių, šimtai buvo sužaloti.

Visuotinei gyventojų apklausai (plebiscitui) surengti buvo sudarytos 2087 rinkimų apylinkès Lietuvoje ir penkios už šalies ribų: Rusijoje - Maskvoje, Smolensko mieste, Tiumenès srities Kogalymo mieste, Arménijoje - Artyko mieste, taip pat Estijoje - Taline. İ balsuotojų sąrašus buvo įrašyti 2652738 balsuotojai. I rinkejjų sąrašus ịrašyti balsuotojai, kuriems yra sukakę 18 metų ir turintys Lietuvos pilietybę arba teisę i Lietuvos pilietybę. Atvyko ị apylinkes balsuoti ir gavo apklausos biuletenius 2247810 asmenų, tai yra 84,43 proc. visų rinkèjų. Iš jų apklausos teiginiui pritare 2 milijonai 28 tūkstančiai 339 balsuotojai, arba 90,47 proc. Nepritarẻ 147 tūkstančiai 39 asmenys, arba 6,56 proc. dalyvavusiųjų apklausoje ${ }^{2}$. Apklausos rezultatų analizė parodè, kad už teiginị "Lietuvos valstybè yra nepriklausoma demokratinè respublika“ pasisakè ne tik lietuviai, bet ir įvairių kitų tautybių asmenys ${ }^{3}$.

1 Žilys, J. Iš konstitucionalizmo istorijos. $1991 \mathrm{~m}$. vasario 9 d. apklausa (plebiscitas) Lietuvos konstitucionalizmo požiūriu. Justitia. 2001, 1: 8.

2 Respublikos rinkimų komisijos pirmininko J. Bulovo pranešimas Lietuvos Respublikos Aukščiausiosios Tarybos 1991 m. vasario 11 d. posèdyje. Lietuvos Respublikos Aukščiausiosios Tarybos (pirmojo šaukimo) antroji sesija. Stenogramos (Nr. 25). Vilnius: Lietuvos Respublikos Seimo leidykla. 1993, p. 437-438. 
Tai, kad visuotinèje gyventojų apklausoje absoliuti dauguma Lietuvos piliečių balsavo už tai, jog rengiamoje naujoje Konstitucijoje būtų ịtvirtinta nuostata „Lietuvos valstybė yra nepriklausoma demokratinè respublika“, tuometės Aukščiausiosios Tarybos deputatus paskatino pagalvoti, kaip šią tautos valios išraišką, - ji nebuvo privaloma, nes dèl nurodyto Konstitucijos teiginio vyko ne referendumas, o visuotine gyventojų apklausa, - paversti privalomu ir ipareigojančiu imperatyvu. Neformaliose deputatų diskusijose buvo siūlomi ịvairūs variantai. Pateikiamos ištraukos iš tuo metu straipsnio autoriaus darytų užrašų atskleidžia, kaip buvo rastas būdas teiginiui „Lietuvos valstybė yra nepriklausoma demokratinè respublika" suteikti konstitucinị teisinị statusą.

\section{Iš dienoraščio}

„1991 m. vasario $11 \mathrm{~d}$. (pirmad.).

Šeštadienị (vasario 9 d.) praleidau namuose. Skyriuje „budejo“ J. Žilys (tuometis Aukščiausiosios Tarybos Juridinio skyriaus vedejas - red. pastaba). Vakare apie 22 val. jis paskambino man ị namus ir paklausè, ką veiksiu rytoj. Supratau, kad sekmadienis pražuvęs, kad teks dirbti. Taip ir buvo. J. Žilys paprašè, kad rytoj 10 val. būčiau pas Č. Stankevičių (tuometis Aukščiausios Tarybos Pirmininko pavaduotojas - red. pastaba), kad reikès dirbti su dokumentais, su kokiais - dar nežino. Pamaniau, kad tikriausiai su Č. Stankevičiaus parengtais projektais. Mačiau tuos projektus, jie nelabai patiko. Ir ne tik man. Kiti teisininkai, su kuriais teko trumpai pasikalbèti apie jų pagrindinę ideją, taip pat buvo tos nuomonès, kad jie nepriimtini. Č. Stankevičius siūlè nustatyti, kad: 1) Aukščiausioji Taryba patvirtina apklausos rezultatus (tai nepriimtina, nes tautos valios niekas negali nei patvirtinti, nei nepatvirtinti, ją galima tik vykdyti!); 2) Aukščiausioji Taryba turi pakeisti galiojančio Laikinojo Pagrindinio Istatymo 1 straipsnị ir įrašyti, kad „Lietuvos valstybė yra nepriklausoma demokratinè respublika“ (tai reikštų, kad nemažai Laikinojo Pagrindinio İstatymo nuostatų neatitiktų 1 straipsnio, nes Laikinajame Pagrindiniame Istatyme yra daug nuostatų, kurios nedera su tikros demokratinès valstybės reikalavimais). Taigi nurodyti Č. Stankevičiaus pasiūlymai man buvo žinomi iš ankstesnių pokalbių su juo; be to, buvau jam pažadejęs jo pasiūlymus aptarti su savo kolegomis Juridiniame skyriuje ir pasakyti bendrą teisininkų nuomonę. Atėjęs ị darbą, Č. Stankevičiaus kabinete jau radau S. Stačioką, dar maždaug po 15 minučių atėjo K. Lapinskas. Diskutavome labai trumpai: S. Stačiokas išdèstė mūsų bendrą poziciją, kad Č. Stankevičiaus pateikti projektai yra nepriimtini, kad reikia ieškoti kito varianto, kad apklausos rezultatus reikia ịtvirtinti kokiu nors kitokiu teisès aktu. Palaikiau S. Stačioką, pasakydamas, kad dèl pateiktų projektų tarèmès Juridiniame skyriuje ir kad teisininkų nuomonè yra vienoda: projektus reikia iš esmès taisyti. Č. Stankevičius sutiko su pateiktais argumentais ir pasakè, kad šiuo atveju reikia teisès akto, kuris turètų ypatingą svorị, kurio negalima būtų pakeisti. Jis lyg tarp kitko paminèjo, kad tai gali būti konstitucinis įstatymas ar konstitucijai prilygintas įstatymas. Eureka! K. Lapinskas, S. Stačio- 
kas ir aš patvirtinome, kad ịvairių pasaulio valstybių teisès sistemose yra tokie įstatymai, kad jie gali būti priimami. Paminejome Švediją, Čekoslovakiją. S. Stačiokas atkreipe dėmesí, kad Lietuvoje konstitucinių ịstatymų niekad nebuvo priimta, bet kodèl nepamèginus to padaryti, kodèl nepradejjus formuoti naujos praktikos. Abu su K. Lapinsku pritarème tokiam požiūriui. Pradejome diskutuoti dèl šio įstatymo turinio. Palaipsniui sudèliojome tokią įstatymo schemą: 1) Aukščiausioji Taryba atsižvelgia ị apklausos rezultatus; 2) apklausos rezultatai ịpareigoja Aukščiausiąją Tarybą; 3) Aukščiausioji Taryba vykdo tautos valią ir 4) nustato, kad tautos pasirinkimas „Lietuvos valstybė yra nepriklausoma demokratinè respublika“ yra valstybės pagrindinis principas. Svarstant ir priimant ịstatymo projektą Aukščiausiojoje Taryboje ši istatymo schema nebuvo pakeista.

Daug vargome, kol radome žodžius kiekvienam šios ịstatymo schemos punktui, bet iki 12 val. jau turejome visą ịstatymo tekstą. Apie 13 val. atejjo V. Landsbergis. Jis perskaité mūsų parengtą ịstatymo projektą ir pasiūle įrašyti dvi naujas nuostatas: 1) „tauta išreiškè savo suvereninę valią, grindžiamą suverenine galia“; 2) „tauta didžiule ir nenuginčijama balsų dauguma pasisake už tai, kad „Lietuvos valstybė yra nepriklausoma demokratinè respublika". Šie pasiūlymai vèl sukèlè diskusiją. Vartème žodynus, skaiteme Aukščiausiosios Tarybos anksčiau priimtus įstatymus, Kovo 11-osios Aktą: bandème išsiaiškinti, ką reiškia formuluote „suvereninė valia, grindžiama suverenine galia“. Pirmininkas atkakliai siekè, kad pritartume jo pasiūlytai formuluotei, šią formuluotę įrašè ị ịstatymo projektą, bet K. Lapinskas, pamatęs, kaip buvo „pataisytas" mūsų parengtas įstatymo projektas, su tokia pataisa kategoriškai nesutiko ir atvirai pasake, jog toks pataisymas yra nepriimtinas. Po ilgų diskusiju buvo rastas kompromisas - $\mathfrak{i}$ ịstatymo projektą įrašyti žodžius „išreiške savo suvereninę galią ir valią".

Dèl V. Landsbergio pasiūlytų žodžių „,tauta didžiule ir nenuginčijama balsų dauguma" diskutuota ne taip aršiai, bet sugaišome dar gerą valandą. Pagaliau pavyko Pirmininką ịtikinti, kad būtų geriau tiesiogiai ịrašyti, jog „,3/4 visų gyventojų, turinčių rinkimų teisę, pasisakè už tai, kad Lietuva yra nepriklausoma demokratinė respublika", o visus procentus ir pan. geriau ịrašyti ị rengiamą Deklaraciją ${ }^{4}$ del Lietuvos dalyvavimo pasaulio valstybių bendrijoje. Taip ir padareme."

\section{Iš dienoraščio}

„1991 m. vasario 11 d., pirmadienĭ, Aukščiausiosios Tarybos plenarinis posèdis prasidejjo 11 val., tačiau greitai buvo padaryta pertrauka iki 17 val., kad deputatai frakcijose galètų aptarti mūsų sekmadienị parengtus projektus. Apie 14 val. man perdavė, kad turiu skubiai eiti pas Č. Stankevičių baigti redaguoti projektų. Jo kabinete 
radau R. Gudaitị, kuris paprašè, kad peržiūréčiau deputatų pataisas, kurios buvo gautos svarstant Deklaracijos projektą. Po kelių minučių atėjo K. Lapinskas. Sutarėme, kad reikia atsižvelgti i K. Motiekos pasiūlymą kitaip suredaguoti vieną Deklaracijos projekto punktą, t. y. įrašyti, kad Lietuva prašo pasaulio valstybių paramos, ragina atsižvelgti ị apklausos rezultatus, kad gera parama Lietuvai būtų tarptautinès konferencijos Baltijos valstybių klausimams aptarti organizavimas ir kt. Šią K. Motiekos pateiktą pataisą tik truputi paredagavome, taip pat nutarėme išplèsti Deklaracijos projekto punktą, kuriame buvo rašoma apie tai, kuo turètų būti remiamasi jungiantis ị tarptautinio bendradarbiavimo procesą: pasiūlème ịrašyti, kad Lietuva vadovaujasi visuotinai pripažintais tarptautinès teisès principais ir normomis ir t. t.

Po to, kai peržiūrèjome Deklaraciją, K. Lapinskas pasakè, kad deputatai siūlo pagalvoti, kaip i konstitucinio ịstatymo projektą ịrašyti, kad apklausos rezultatus galima pakeisti ne mažesne Lietuvos gyventojų balsų dauguma, negu ta, kuria buvo pritarta apklausai pateiktam teiginiui. Pasiūliau pratęsti įstatymo antrą straipsnị ir ịrašyti sakinị ,jeigu už tai pasisakytų ne mažiau kaip 3/4 visų Lietuvos piliečių, turinčių aktyviąją rinkimų teisę“. K. Lapinskas sutiko, taip ir įrašème ị projektą. <...>

Bibliotekoje sutikau deputatą V. Andriukaitį. Jis ieškojo, kaip žodis „plebiscitas“ aiškinamas enciklopedijose. Surado, kad tarptautinejje teisejje šis žodis dažniausiai vartojamas tais atvejais, kai tauta apsisprendžia dèl tam tikros teritorijos statuso. Jo nuomone, vartoti šią sąvoką mūsų parengtame isstatymo projekte ir kituose dokumentuose yra neteisinga, nes ir užsienyje, ir Lietuvoje atitinkamas sąvokas reikia suprasti vienodai. Nesutikau, kad plebiscito sąvoką reikia suprasti tik taip siaurai, kaip ją aiškina V. Andriukaitis. Bandžiau argumentuoti, kad ši sąvoka gali būti aiškinama ir kitaip, kad jos turinys yra daug platesnis, kad ši sąvoka nèra susijusi tik su tautos apsisprendimu dèl teritorijos statuso. Ypač dabar, kai pasaulio valstybèse mūsų apklausa yra suprantama kaip tautos nuomonès išreiškimas, t. y. kaip tikras plebiscitas. Argi mes galime atsisakyti tokios plebiscito sąvokos sampratos ir išbraukti ją iš isstatymo projekto?! Pasakiau, kad Juridiniame skyriuje turime sukaupę nemažai medžiagos, kurioje ši sąvoka aiškinama ịvairiai, kad galiu šią medžiagą perduoti pasižiūrèti. Nuejjome ị skyrių. Ten radau deputatą N. Rasimavičių, kuriam anksčiau buvau perdavęs medžiagą, aiškinančią sąvokos „plebiscitas“ turinị. Jis sutiko tą medžiagą parodyti V. Andriukaičiui. Nežinau, ar mano paaiškinimai bei medžiaga, su kuria V. Andriukaitis susipažino, jị itikino, bet šiuo klausimu plenariniame posèdyje jis nekalbejo, nors prieš tai sakè, jog būtinai dalyvaus diskusijoje, nes mes elgiamès nekorektiškai, vartojame sąvokas, kurios turi visiškai kitokią reikšmę negu ịprasta.

Svarstymas Aukščiausiosios Tarybos posėdyje praejo ramiai. Buvo kai kurių pasiūlymų taisyti ịstatymo projekto tekstą, bet jie buvo neesminiai, tik redakcinio pobūdžio. Pavyzdžiui, vietoj žodžių „pamatinis principas“ buvo siūloma ịrašyti „pagrindinis principas“, kai kur vietoje žodelio „ar“ padeti kablelị ir pan. İdomiausias buvo pasiūlymas pataisyti įstatyme ịtvirtintą nuostatą "pamatinis valstybès principas gali būti pakeistas tik visuotinès apklausos (plebiscito) būdu“. Vienas deputatas 
pasiūle po žodžio "plebiscito“ įrašyti žodị „referendumo“, taigi ịstatyme atsirastų sąvoka "plebiscito referendumo būdu“. Šis pasiūlymas buvo argumentuojamas tuo, kad referendumo sąvoka yra platesnè negu plebiscito sąvoka, kad būtina atsižvelgti $\mathfrak{i}$ tai, kad priimamas ne bet koks, o konstitucinis ịstatymas. Jeigu šis pasiūlymas būtų priimtas, tikrai sukurtume naują teisinę sąvoką („plebiscitas referendumas“), kurios turinị būtų labai sunku paaiškinti. Tai kas Lietuvoje ịvyko: „apklausa (plebiscitas)“ ar "plebiscitas referendumas“? Tai visiškai skirtingi dalykai. Gerai, kad Č. Stankevičius greitai susivokè ir nesutiko su tokiu pasiūlymu. Buvo ir kitų smulkių redakcinių pastabèlių, bet jos nekeitė projekto esmès. Aukščiausioji Taryba prièmé mūsų parengtą įstatymo projektą. Visa tai, kas vyko salèje, stebejjau iš balkono. Salè buvo pilna, kaip Kovo 11-ąją. Pranešimą apie apklausos rezultatus perskaitė J. Bulovas, Respublikos rinkimų komisijos pirmininkas. Rengdamasis šiam pranešimui, sekmadienị jis kelis kartus buvo atejęs ị mūsų darbo grupę, kai buvome susirinkę pas Č. Stankevičių. Paskaitė mums kelias vietas iš savo parengto pranešimo. Jos nevisiškai atitiko tą dvasią, kurią norèjome atspindèti konstituciniame ịstatyme, todèl galèjo sukelti nevienareikšmių vertinimų. Č. Stankevičius ir V. Landsbergis padejjo jam suformuluoti pagrindinius pranešimo teiginius: apklausos rezultatai - tai tautos valia; ją turime vykdyti; tautos valios niekas negali pakeisti, tik pati tauta, ir kt. Pranešimą J. Bulovas skaitè sunkiai, tačiau visos pagrindinès tezès, kurias jam buvo pasiūlyta ịrašyti ị pranešimą, buvo pasakytos. Po to kalbẻjo Pirmininkas. Jis akcentavo politinę apklausos reikšmę, pasakè, kad dabar niekas negali abejoti mūsų tautos valia. Konstitucinio įstatymo projektą Aukščiausiajai Tarybai pristatė Č. Stankevičius. Jis pateikè ịvairių argumentų, kodèl būtina priimti tokị ịstatymą. Prieš tai dèl jų diskutavome projekto rengimo grupeje. Nors jie mums buvo žinomi iš anksto, bet dabar skambejjo dar įtikinamiau. Tačiau vienas prieš tai projekto rengimo grupejje neaptartas argumentas priverte suklusti: Č. Stankevičius pareiškè, kad surengta apklausa (plebiscitas) yra aukštesnè už referendumą. Tokio argumento teisiškai neįmanoma pagrịsti. Tačiau buvo pasakyta būtent tokia tezè. Tai dar kartą patvirtino, kad ne teisininkai su teisinėmis sąvokomis ir kategorijomis dažnai elgiasi gana laisvai $<\ldots .>$. Kita vertus, argi ne paradoksalu, kad būtent visiškai atsitiktinè ne teisininko, bet inžinieriaus Č. Stankevičiaus užuomina apie „konstitucinị ịstatymą“" buvo labai svarbi atrandant tinkamiausią teisės akto, kuriuo galima buvo išreikšti apklausos rezultatus, formą.

Priimant konstitucini ịstatymą buvo susidurta su dar viena netikèta kliūtimi. Prieš pat Aukščiausiosios Tarybos posèdį, kuriame turejjo būti priimamas šis ìstatymas, ị Juridinị skyrių atbègo Lory Vyman (teisininke iš JAV, kuri JAV lietuvių bendruomenés prašymu atvyko į Lietuvą kartu su savo vyru B. Džonsonu padèti Lietuvos teisininkams rengti ịvairius teises aktus - red. past.) ir tiesiog užpuole mane ir J. Žilį dèl pavadinimo „konstitucinis įstatymas“. Ji pasibaisèjo, iš kur mes ištraukème tokį pavadinimą, tai esą tèra tik sovietinès teisès teorijoje sugalvotas dalykas, niekas Vakarų pasaulyje tokio pavadinimo nesupras. Dar pridūrè, kad mes su J. Žiliu neži- 
nome, kas yra teisès aktų hierarchija, nesuprantame, jog konstitucinis įstatymas - tai ne kas kita, kaip pati konstitucija, ir pan. L. Vyman pasiūle mums tuojau pat nusileisti ì Aukščiausiosios Tarybos posėdžių salę ir sustabdyti konstitucinio ịstatymo prièmimą! Toks karštas ịtikinèjimas ir atkaklumas mus su J. Žiliu net sutrikdè. J. Žilys pradžioje pabandè „atsimušti“, sakydamas, kad jis tiesiogiai nedalyvavo rengiant ši projektą, kad su juo buvo tik konsultuojamasi. Vèliau abu pabandème argumentuoti, kad konstitucinių ịstatymų sąvoka nèra jokia naujiena, kad tokių įstatymų yra Švedijoje, Čekoslovakijoje ir kitose valstybėse, kad tai aktas, esantis greta konstitucijos. Tačiau šie argumentai jos neįtikino, ji net atšovė, kad Lietuva kol kas neturi savo konstitucijos. Pasiūlème jai kreiptis ị K. Lapinską, jis dalyvavo rengiant projektą, jis gali pasakyti savo nuomonę kaip Aukščiausiosios Tarybos deputatas. L. Vyman nuejjo ị Aukščiausiosios Tarybos posėdžių salę, tačiau ir ten nieko nepešè. K. Lapinskas jos nepalaikè. Priešingai, jis labai aiškiai pasakè, kad konstitucinio įstatymo sąvoka yra visiškai priimtina ir apskritai - koks jos reikalas, kas ir kaip Lietuvoje turi priimti konstituciją ir ịstatymus. Tai labai užgavo L. Vyman ir jos vyrą B. Džonsoną, kurie, beje, dažnai elgdavosi taip, lyg jie vieni supranta, kas yra teisè ir ịstatymų leidyba, o Lietuvoje esą to niekas nesupranta arba supranta labai mažai. Kitą dieną B. Džonsonas net nepasisveikino su Š. Adomavičiumi (tuomečiu Aukščiausiosios Tarybos Pirmininko padejjeju - red. past.), nes, kaip sakè, „esu labai piktas, kad mūsų su L. Vyman nepaklausète“.

Kaip vertinti L. Vyman argumentus? Juos galima ginčyti, nes konstitucinio ịstatymo sąvoka, kaip minèjau, yra vartojama įvairiose pasaulio valstybèse. Ši įstatymą, kuriame įtvirtinome apklausos rezultatus, reikejjo kaip nors atskirti nuo kitų, vadinamųjų „paprastųjų“ i̇statymų. Be to, teisès norma, kuri įrašyta šiame ịstatyme, yra ypatinga, tai pagrindinè ir svarbiausia norma, kurios pagrindu bus rengiama nauja konstitucija, nustatyta valstybės valdymo forma, vidaus ir užsienio politika. Konstituciniame i̇statyme nustatyta ypatinga šios teisès normos keitimo tvarka: tik gyventojų apklausos tvarka ir tik jeigu už tai pasisakys ne mažiau kaip 3/4 visų piliečių, turinčių rinkimų teisę. Ši teisès norma egzistuos greta Laikinojo Pagrindinio İstatymo, nesikirs su juo turiniu. Ir dar vienas dalykas: niekas nedraudžia mums iš pradžių nustatyti naujos konstitucijos kūrimo pagrindą, o po to, vadovaujantis tuo pagrindu, rengti kitus įstatymus ir pačią konstituciją. Tai argumentai už sąvokos „konstitucinis isstatymas" vartojimą. Kai paklausiau deputato E. Jarašiūno, kaip jis vertina tai, kad pradejome vartoti naują sąvoką „konstitucinis įstatymas“, jis atsaké, kad vertina labai teigiamai, nes tai yra maksimumas, ką šioje situacijoje galejome padaryti, pasinaudodami apklausos rezultatais.

Žinoma, ši konstitucinị ịstatymą vertinant tik griežtu teisiniu požiūriu galima pastebèti, kad jis turi ir kai kurių silpnųjų vietų. Pirma, apklausa buvo sumanyta ir paskelbta kaip neturèsianti privalomojo pobūdžio, kaip tautos nuomonès atsiklausimas, t. y. jos rezultatai, kad ir kokie būtų, savaime netampa teisés norma. Tai lyg 
pasitarimas, konsultacija. Dabar, kai apklausos rezultatai labai geri, juos iš karto bandoma traktuoti kaip privalomus. Antra, Aukščiausiosios Tarybos 1991 m. sausio 16 d. nutarime dèl apklausos ši akcija taip ir vadinama - apklausa. Tačiau vèliau, komentuojant ịvykusios apklausos rezultatus, vis dažniau pradedama vartoti žodị „plebiscitas“; dar vèliau pareiškiama, kad apklausa savo teisine galia yra net aukštesnè už referendumą, vadinasi, jeigu referendumo rezultatai yra privalomi ir referendumu priimtas sprendimas veikia (taikomas) tiesiogiai, tai dar daugiau yra privalomas apklausos būdu (plebiscitu) priimtas sprendimas. Trečia, Aukščiausioji Taryba nustate ypatingą šios teisės normos keitimo tvarką, kai reikia net 3/4 rinkejų balsų. Tačiau tai yra Aukščiausiosios Tarybos sprendimas, o ne tiesiogiai tautos nustatyta taisyklé, todèl nauja Aukščiausioji Taryba, kad ir kaip būtų gaila, vis dèlto panorëjusi turès galimybę pakeisti ypatingą šios normos keitimo tvarką. Taigi apklausos rezultatų teisinè apsauga, numatyta konstituciniame ịstatyme, nèra tokia tvirta, kaip to norètųsi ir kaip tai atrodo iš pirmo žvilgsnio.

Štai tokios dvi pozicijos, dvi argumentacijos. Apie tai reikia galvoti, nes mūsų valstybės priešininkai gali mėginti pasinaudoti priimto konstitucinio įstatymo silpnomis vietomis. Su J. Žiliu dèliojame visus argumentus „už“ ir „prieš“. Gal prireiks. Keista, bet L. Vyman apie silpnąsias konstitucinio ịstatymo vietas net neužsiminé, nors, turint piktos valios, jos duoda tam tikrą pagrindą ịvelti teisinę visuomenę $\mathfrak{i}$ teorini ginçą dèl konstitucinio įstatymo sąvokos vartojimo, taigi, ir dèl viso priimto konstitucinio įstatymo. Matyt, ateityje dar teks nemažai diskutuoti, ar turejome teisini pagrindą ir ar pagrịstai pradejjome vartoti iki šiol Lietuvos teisés sistemoje nežinomą sąvoką „konstitucinis įstatymas“. Svarbiausia, kad Laikinasis Pagrindinis İstatymas - o tai yra mūsų Laikinoji Konstitucija, nenumato tokios teisės akto rūšies kaip konstitucinis ịstatymas. Laikinajame Pagrindiniame İstatyme rašoma tik apie įstatymus, o apie konstitucinius įstatymus net neužsimenama. Laikas parodys, ar nauja teisinè sąvoka „konstitucinis įstatymas" prigis Lietuvos teisés sistemoje, ar ši sąvoka turi ateiti. Po to, kai šis ịstatymas Aukščiausiosios Tarybos buvo priimtas, Juridiniame skyriuje dèl jo iš naujo diskutavome su L. Vyman. Pagrindinis dalykas: ar nesuklydome? Vienu metu J. Žilys net buvo linkęs palaikyti L. Vyman nuomonę, kad galbūt padaryta klaida: jis pareiškè, kad gal reikẻjo ne konstitucinio įstatymo, o deklaracijos. Bet jo abejonès truko labai neilgai. Diskutuojant jis vis labiau linko ị tai, kad konstitucinio įstatymo sąvoka yra visiškai priimtina, nors, jo nuomone, sprendimą priimti būtent „konstitucinị ịstatymą" lèmé ne teisiniai, o politiniai motyvai. Baigèsi tuo, kad J. Žilys atvirai pasakè: „Konstitucinis ịstatymas jau yra priimtas, todèl aš dẻl jo daugiau nediskutuosiu ir negilinsiu šios diskusijos kur nors kitur." Tą patị padaryti jis pasiūlè ir L. Vyman. J. Žilys tiesiai paklausè: „Ką Jūs man atsakysite, jeigu pasakysiu, jog tokia yra ịstatymų leidejo valia?" L. Vyman nusišypsojo ir atsakè: „Prieš tokį argumentą aš neturiu jokių kontrargumentų, bet mums šiuo klausimu dar teks diskutuoti.“ 


\section{Konstitucinių įstatymų institutas 1992 m. Konstitucijoje}

Priẻmus minètą konstitucinị ịstatymą, jokių platesnių teisinių diskusijų dẻl jo nekilo. Konstitucinio ịstatymo sąvoka buvo prisiminta, kai, rengiant 1992 m. Konstitucijos projektą, užvirè ginčai, kaip užtikrinti, kad tam tikrų ypač svarbių santykių teisinis reguliavimas būtų stabilus, kad jo nebūtų galima lengvai pakeisti. Pradžioje buvo galvojama tokius santykius nurodyti pačioje Konstitucijoje, bet deputatams nepavyko susitarti, kokie santykiai yra ypač svarbūs ir turi būti nurodyti Konstitucijoje, kad jų reguliavimas būtų stabilus. Kai atrodè, jog susitarti nepavyks, buvo prisiminta, kad yra priimtas Konstitucinis ịstatymas „Dèl Lietuvos valstybès“, kad ji pakeisti sunkiau negu paprastąj i istatymą ir kad jis traktuojamas kaip turintis didesnę teisinę galią negu paprastasis ịstatymas. Buvo nutarta ị naujai rengiamą Konstituciją įrašyti nuostatą, kad Seimas galès nustatyti konstitucinių ịstatymų, kurie reguliuos ypač svarbius visuomeninius santykius, sąrašą, kad konstituciniams įstatymams priimti ir pakeisti reikès didesnès balsų daugumos negu ta, kurios reikia priimant ir keičiant paprastuosius įstatymus, kad konstitucinis ịstatymas turès didesnę teisinę galią negu paprastasis ịstatymas. Konstitucijos projekto rengèjų nuomone, tai turèjo užtikrinti atitinkamų santykių teisinio reguliavimo stabilumą.

Šiame straipsnyje nekeliamas tikslas plačiai nagrinèti šiuo metu galiojančioje Konstitucijoje ịtvirtintų konstitucinių ịstatymų sampratą. Ji išsamiai atskleista Lietuvos Respublikos Konstitucinio Teismo jurisprudencijoje $e^{5}$ taip pat teisès mokslineje literatūroje ${ }^{6}$. Pabréšime tik tai, kad $1992 \mathrm{~m}$. vasario $11 \mathrm{~d}$. konstitucinis įstatymas „Dèl Lietuvos valstybès“ yra ịtrauktas ị $1992 \mathrm{~m}$. Konstituciją ${ }^{7}$ kaip jos sudedamoji dalis (Konstitucijos 150 str.). Konstitucijos sudedamoji dalis taip pat yra 1992 m. birželio $8 \mathrm{~d}$. konstitucinis aktas „Dèl Lietuvos Respublikos nesijungimo i̇ postsovietines Rytų sąjungas“, 1992 m spalio 25 d. ịstatymas „Dèl Lietuvos Respublikos Konstitucijos ịsigaliojimo tvarkos“ ir 2004 m. liepos 13 d. konstitucinis aktas „Dèl Lietuvos Respublikos narystės Europos Sąjungoje“. Taigi konstituciniam įstatymui „Dèl Lietuvos valstybès" tapus Konstitucijos sudedamąja dalimi, jo teisinè galia yra tokia pati, kaip ir visos Konstitucijos, t. y. jis, kaip ir visos kitos Konstitucijos nuostatos, turi aukščiausią teisinę galią. Kartu Konstitucijoje yra ịtvirtinti kitos rūšies konstituciniai ìstatymai: vadinamieji „sąrašiniai“ konstituciniai ìstatymai (Konstitucijos 69 str. 3 d.) ir ístatymai, kurie atskiruose Konstitucijos straipsniuose ịvardijami kaip konstituciniai ịstatymai (iki šiol toks konstitucinis ịstatymas nurodytas tik Konstitucijos

5 Konstitucinio Teismo 1993 m. lapkričio 8 d., 1994 m. gruodžio 1 d., 1994 m. gruodžio 22 d., 2000 m. spalio 18 d., 2001 m. balandžio 2 d., 2002 m. gruodžio 24 d., 2006 m. kovo 14 d. nutarimai.

6 Žr., pavyzdžiui, Sinkevičius, V. Konstitucinių ịstatymų samprata: teoriniai aspektai. Jurisprudencija. 2008, 2(104): 28-38. 
47 str. 3 d., pagal kurią „žemę, vidaus vandenis ir miškus ịsigyti nuosavybẻn Lietuvos Respublikoje užsienio subjektai gali pagal konstitucini įstatymą “8). "Sąrašinių“" konstitucinių ịstatymų ir Konstitucijos 47 str. 3 d. nurodyto konstitucinio įstatymo pagal jų teisinę galią ir keitimo tvarką negalima sutapatinti su Konstitucijos 150 str. nurodytais konstituciniais įstatymais (konstituciniais aktais)" ${ }^{9}$ taigi ir su $1992 \mathrm{~m}$. vasario $11 \mathrm{~d}$. konstituciniu ịstatymu „Dèl Lietuvos valstybès“. Pagrindinis skirtumas yra tai, kad Konstitucijos 150 str. nurodyti konstituciniai ịstatymai (konstituciniai aktai) turi tokią pačią teisinę galią, kokią turi visa Konstitucija, t. y. aukščiausią teisinę galią, jie gali būti pakeisti tik tokia pačia tvarka, kuria gali būti keičiama Konstitucija (147-149 str.). O „sąrašiniai“ konstituciniai ịstatymai (69 str. 3 d.) ir Konstitucijos 47 str. 3 d. nurodytas konstitucinis ịstatymas, reguliuojantis žemès pardavimą užsieniečiams, gali būti pakeisti kitokia, lengvesne tvarka: jiems pakeisti taikoma ne Konstitucijos keitimui nustatyta tvarka, o Konstitucijos 69 str. 3 d. nustatyta tvarka, t. y. „sąrašiniai“ konstituciniai įstatymai priimami daugiau kaip pusès visų Seimo narių balsų dauguma, o keičiami ne mažesne kaip 3/5 visų Seimo narių balsų dauguma. Tokia pačia balsų dauguma gali būti priimtas ir pakeistas Konstitucijos 47 str. $3 \mathrm{~d}$. nurodytas konstitucinis ịstatymas.

İsigaliojus 1992 m. spalio 25 d. priimtai Konstitucijai, Seimui ilgą laiką nepavyko sudaryti konstitucinių ịstatymų sąrašo. Taip buvo dèl to, kad ị konstitucinị ịstatymą, kuriuo turëjo būti nustatytas konstitucinių ịstatymų sąrašas, norèta įrašyti labai daug ịvairių konstitucinių ịstatymų, bet Seimo narių nuomonès dèl to, kokie ịstatymai turètų būti įrašyti ị tą sąrašą, labai išsiskyrè. Tuometẻ Seimo dauguma sieké ị konstitucinių istatymų sąrašą įrašyti kuo daugiau konstitucinių įstatymų, nes žinojo, kad jai pakanka balsų priimti ị konstitucinių ịstatymų sąrašą įrašytus konstitucinius istatymus, - minèta, kad pagal Konstitucijos 69 str. 3 d. tam reikia 71 Seimo nario balso. Seimo dauguma žinojo ir tai, kad naujam Seimui bus labai sunku pakeisti jos priimtus konstitucinius ịstatymus, nes tam reikès net 3/5 visų Seimo narių balsų. Tai gerai suvoke ir Seimo mažuma, todèl ji labai priešinosi tam, kad ị konstitucinių ịstatymų sąrašą būtų ịrašyta daug konstitucinių ịstatymų. Tuometẻ Seimo mažuma, tikèdamasi laimèti ateinančius Seimo rinkimus, nebuvo užtikrinta, kad Seime turès net $3 / 5$ vietų, - būtent tiek balsų reikia norint pakeisti konstitucinị ịstatymą. Tuometė Seimo mažuma, tikèdamasi po naujų Seimo rinkimų tapti Seimo dauguma, nenorejo

Seimas 1996 m. birželio 20 d. priemė Lietuvos Respublikos Konstitucijos 47 str. antrojoje dalyje numatyto žemės sklypų ịsigijimo nuosavybèn subjektų, tvarkos, sąlygų ir apribojimų konstitucinị ịstatymą. Valstybès žinios. 1996, Nr. 64-1503. Vèliau šio konstitucinio įstatymo pavadinimas buvo pakeistas taip: „Lietuvos Respublikos Konstitucijos 47 straipsnio 3 dalies igyvendinimo konstitucinis įstatymas“. Valstybès žinios. 2003, Nr. 34-1418.

9 Deja, teisès mokslineje literatūroje vadinamieji „sąrašiniai“ konstituciniai ịstatymai (Konstitucijos 69 str. 3 d., 72 str. 2 d.) neretai painiojami su Konstitucijos 150 str. nurodytais konstituciniais įstatymais (konstituciniais aktais). Žr., pvz., Vaišvila, A. Teisés teorija. Vilnius: Justitia, 2000, p. 249. 
būti suvaržyta ankstesnio Seimo priimtų konstitucinių įstatymų, ji norèjo turèti daugiau galimybiu pakeisti ankstesnio Seimo priimtais konstituciniais įstatymais nustatytą teisinį reguliavimą. Tai buvo pagrindinè priežastis, kodèl Seimui ilgą laiką nepavyko priimti konstitucinio įstatymo, nustatančio konstitucinių įstatymų sąrašą. Negalima nepasakyti ir to, kad būta ir tokių projektų, kurie rodo, kad jų autoriai visiškai neskiria konstitucinių įstatymų, kurie yra Konstitucijos sudedamoji dalis (taigi turi pačios Konstitucijos galią), nuo tų konstitucinių ịstatymų, kurie nèra Konstitucijos sudedamoji dalis (taigi jų teisinè galia yra mažesnè negu Konstitucijos) ${ }^{10}$. Mègindamas nustatyti konstitucinių ịstatymų sąrašą Seimas buvo pasirinkęs ir vadinamąji „tuščio lapo" principą, kurio esmę galima apibūdinti taip: Seimas, esant dideliam politinių jegų sutarimui, priima atskirą konstitucinị ịstatymą ir jị ịrašo ị konstitucinių įstatymų sąrašą, kurio realiai dar nèra, t. y. priimtas konstitucinis ịstatymas įrašomas i „tuščią lapą". Pasirinkus minètą principą, konstitucinių ỉstatymų sąrašas būtų sudaromas ne visas iš karto, o palaipsniui, įrašant vis naujus konstitucinius įstatymus. Pažymettina, kad toks konstitucinių ịstatymų sąrašo sudarymo principas yra nesuderinamas su Konstitucija, todèl tokị konstitucinio įstatymo ịrašymą ị konstitucinių įstatymų sąrašą Konstitucinis Teismas $2002 \mathrm{~m}$. gruodžio 24 d. nutarime įvertino kaip fiktyvų ${ }^{11}$. Tik pavykus Seimo nariams sutarti, kad ị konstitucinių ịstatymų sąrašą bus įrašyti tik tokie konstituciniai įstatymai, kurie nekelia didesnių ginčų dẻl to, kad jais nustatytasis teisinis reguliavimas turi būti stabilesnis negu nustatytasis paprastaisiais ịstatymais, Seimui pavyko nustatyti konstitucinių ịstatymų sąrašą. Tai padaryta $2012 \mathrm{~m}$. kovo 15 d. priimtu Konstitucinių ịstatymų sąrašo konstituciniu įstatymu ${ }^{12}$.

Grižkime prie $1991 \mathrm{~m}$. vasario $9 \mathrm{~d}$. ̨̣vykusios visuotinès apklausos (plebiscito) ir $1991 \mathrm{~m}$. vasario $11 \mathrm{~d}$. priimto konstitucinio įstatymo „Dèl Lietuvos valstybès“. Visuotinès apklausos (plebiscito) paskirtis teisès mokslinèje literatūroje kartais aiš-

10 Antai 2006 m. spalio 18 d. Seime buvo ịregistruotas Lietuvos Respublikos konstitucinių ịstatymų sąrašo konstitucinio ịstatymo projektas (Reg. Nr. XP-1558A), kuriuo ị konstitucinių įstatymų sąrašą siūlyta ịrašyti inter alia $1991 \mathrm{~m}$. vasario $11 \mathrm{~d}$. Konstitucinį ịstatymą „Dẻl Lietuvos valstybès“, 1992 m. birželio 8 d. Konstitucinị aktą „Dèl Lietuvos Respublikos nesijungimo i postsovietines Rytų sąjungas“, 1992 m. spalio 25 d. İstatymą „Dèl Lietuvos Respublikos Konstitucijos įsigaliojimo tvarkos“, 2004 m. liepos 13 d. Konstitucinį aktą „Dèl Lietuvos Respublikos narystès Europos Sąjungoje“. Pasiūlymas ịrašyti ị konstitucinių ịstatymų sąrašą minètus teisès aktus reiškia, kad šiems teisès aktams, kurie pagal Konstitucijos 150 str. yra Konstitucijos sudedamoji dalis (taigi turi Konstitucijos galią), buvo norima suteikti mažesnę galią, t. y. „sąrašinio“ konstitucinio ịstatymo galią. Kadangi konstituciniai ịstatymai, kurie yra Konstitucijos sudedamoji dalis, gali būti keičiami tik ta pačia tvarka, kaip ir pati Konstitucija, minètas pasiūlymas reiške ir tai, kad buvo siūloma nepaisyti Konstitucijos 148 str. nustatytos Konstitucijos keitimo tvarkos. Kitaip tariant, pamatines Konstitucijos nuostatas, kurios gali būti keičiamos tik referendumu, buvo siūloma pakeisti - jų teisinès galios aspektu - priimant aptariamą konstitucinių ịstatymų sąrašo konstitucinị ịstatymą. Pabrežtina, kad Konstitucija to daryti neleidžia.

11 Konstitucinio Teismo 2002 m. gruodžio 24 d. nutarimas. Valstybés žinios. 2003, Nr. 19-828.

12 Valstybès žinios. 2012, Nr. 36-1772. 
kinama taip: „prieš pradedant rengti būsimos kodifikuotos rašytinès konstitucijos (1992 m. - autoriaus past.) projektą, buvo nuspręsta, jog nuostatą dèl valstybès suvereniteto ir valstybès formos, kuri jau buvo konstatuota Kovo 11-osios akte ir Laikinajame Pagrindiniame İstatyme, reikia ịtvirtinti surengiant visuotinę apklausą - plebiscitą, taip suteikiant šiai normai konstitucinị statusą"13, ir kad „1991 m. vasario $9 \mathrm{~d}$. plebiscitas, remdamasis tautos suvereniteto principu, galutinai legitimavo $1990 \mathrm{~m}$. kovo $11 \mathrm{~d}$. Nepriklausomybès akta "14. Taip apibrèžiant visuotinès apklausos paskirtį, mėginama remtis Aukščiausiosios Tarybos posèdžių stenogramomis, kuriose iš tiesų yra deputatų kalbų, sudarančių prielaidų teigti, kad nuostatai dèl Lietuvos valstybės suvereniteto ir valstybės formos reikejjo suteikti konstitucinị statusą surengiant visuotinę apklausą (plebiscitą). Antai Č. Stankevičius, Aukščiausiosios Tarybos 1991 $\mathrm{m}$. vasario $11 \mathrm{~d}$. plenariniame posèdyje pateikdamas konstitucinio įstatymo projektą, kalbejo, kad „,̌is tautos sprendimas priimtas dèl pamatinio valstybès principo ir konstitucinès normos" ${ }^{\text {"15 }}$, o Respublikos rinkimų komisijos pirmininkas J. Bulovas, informuodamas Aukščiausiąją Tarybą apie visuotinès apklausos rezultatus, pabrèžè, jog „visuotinè apklausa išsprendè ne vien tautos apsisprendimo už Lietuvos nepriklausomybę teisinį klausimą, bet ir pasisakè už valstybès formą - už respubliką ir už valdymo formą - už demokratiją <...> “16. V. Landsbergis savo pranešime apie plebiscitą teigé, kad „padarème pagrindinị teisinị - konstitucinị sprendimą, kuris yra ir mūsų politinis ginklas" ${ }^{\text {"17. }}$. Bet ar nurodytosios ir kitų deputatų kalbos reiškia, kad visuotinè apklausa (plebiscitas) buvo surengta tam, kad nuostatai dèl Lietuvos valstybès suvereniteto ir valstybės formos reikejjo suteikti konstitucinį statusą? Nuodugnesnè Aukščiausiosios Tarybos posèdžių stenogramų analizè, ypač žinant visuotinés apklausos paskelbimo ir konstitucinio įstatymo rengimo bei prièmimo kontekstą, paneigia minètus teiginius dèl visuotinès apklausos paskirties. İdèmiau pažvelkime i Č. Stankevičiaus pasakytą kalbą. Aukščiausiosios Tarybos plenariniame posédyje pateikdamas konstitucinio ịstatymo „Dèl Lietuvos valstybès“ projektą jis pabrěžè: „tautos sprendimas <...> dar neturi teisinès išraiškos“; „Lietuvos Respublikos Aukščiausiosios Tarybos garbinga pareiga yra Lietuvos tautos, jos visų tautybių žmonių priimtam sprendimui suteikti teisinę formą. Suteikdami priimtam sprendimui teisinę formą mes reikštume tautos valią teisiniu aktu ir vykdytume tautos priimtą sprendimą“; „suformuluotas ir plebiscitu priimtas teiginys „Lietuvos valstybé yra nepriklausoma demokratinè respublika " tampa galiojančia Lietuvos konstitucijos norma“; „mes siūlome priimti ṣ̌ Konstitucinị ịstatymą dèl Lietuvos valstybès, kuris

13 Vaičaitis, V. Konstituciniu istatymu fenomenas. Vilnius: Teisinès informacijos centras, 2004, p. 77.

14 Ibid., p. 78.

15 Lietuvos Respublikos Aukščiausiosios Tarybos (pirmojo šaukimo) antroji sesija. Stenogramos (Nr. 25), supra note 2, p. 444.

16 Ibid., p. 438.

17 Ibid., p. 440. 
galiotų kartu su Laikinuoju Pagrindiniu İstatymu, nesueidamas su juo ị koliziją, ir kartu ịtvirtintų tiesioginiu piliečių balsavimu priimtą konstitucinę normą, kad Lietuvos valstybė yra nepriklausoma demokratinè respublika, tą normą, kuri privalomai būtų ịrašyta pirmuoju straipsniu ị Lietuvos Respublikos Konstituciją“. Čia išdèstytų Č. Stankevičiaus teiginių esmé tokia: tauta išreiške savo valią, tačiau ta valia dar neturi teisinès išraiškos; tautos priimtam sprendimui Aukščiausioji Taryba turi suteikti teisinę formą, tai reikia padaryti priimant konstitucinị ịstatymą. Kitų argumentų, kodèl reikia priimti konstitucini įstatymą, Aukščiausiosios Tarybos plenariniame posèdyje nebuvo pateikta. Tai leidžia manyti, kad deputatai būtent taip suprato visuotinès apklausos (plebiscito) ir konstitucinio įstatymo santyki.

Aiškinimas, kad per visuotinę apklausą (plebiscitą) išreikšta piliečių valia esą pati tiesiogiai sukūrè teisès normą, būtų nepagrịstas dèl kelių priežasčių. Jeigu visuotinès apklausos (plebiscito) būdu išreikšta piliečių valia pati tiesiogiai sukūrè teisès normą, tai kam reikèjo priimti konstitucinị ịstatymą, kuris, kaip minèta, turejo suteikti piliečių išreikštai valiai teisinę formą? Konstitucinị ịstatymą reikejo priimti būtent dèl to, kad visuotinès apklausos (plebiscito) būdu išreikšta piliečiu valia pati tiesiogiai nesukūrè teisès normos. Piliečių valia buvo pagrindas atsirasti teisés normai, kuri buvo ịtvirtinta konstituciniame ịstatyme. Aukščiausioji Taryba negalèjo nepaisyti visuotinès apklausos (plebiscito) būdu išreikštos piliečių valios. Kita vertus, tai, kad buvo surengta visuotinè apklausa (plebiscitas), savaime nesuponavo Aukščiausiosios Tarybos pareigos priimti konstitucinị ịstatymą ar kitą teisės aktą, suteikiantị teiginiui, kuriam buvo pritarta per visuotinę apklausą (plebiscitą), atitinkamą teisinę išraišką. Prieš priimant politinị sprendimą dèl tautos valios atsiklausimo buvo daug diskutuojama, kaip turi būti atsiklausta tautos. Apklausos, o ne referendumo ${ }^{18}$ forma buvo pasirinkta neatsitiktinai, bet apsvarsčius visus galimus apklausos rezultatus, taip pat ir neigiamus. Antai, kokios pasekmès kiltų ir ką reikètų daryti, jeigu piliečių nuomonès labai išsiskirtų, jeigu pritariančiųjų pateiktam teiginiui būtų maždaug tiek pat, kiek ir nepritariančiųjų, ar, blogiausiu atveju, būtų pareikštas nepritarimas pateiktajam teiginiui. Apie tai reikèjo galvoti, „<...> juk tiek daug buvo įdèta pastangų sutrikdyti žmones, nuteikti juos prieš jų pačių išrinktą valdžią, sukiršinti tarpusavyje arba pasèti ir ịskiepyti nusivylimą, seną stagnacijos laiką, abejingumą “19. Todèl Aukščiausiosios Tarybos1991 m. sausio 16 d. nutarimas „Dèl Lietuvos Respublikos gyventoju apklausos“ buvo suformuluotas labai trumpai ir neutraliai: „Pavesti Vyriausybei ir savivaldybėms surengti Lietuvos Respublikos gyventojų, turinčių Lietuvos pilietybę ar pilietybės teisę pagal Lietuvos Respublikos pilietybės įstatymą, visuotinę apklau-

18 Tuo metu galiojo Referendumo ịstatymas, kurio 7 str. buvo numatyta, kad referendumu gali būti priimami ịstatymai ir sprendžiami kiti svarbūs valstybinio gyvenimo klausimai. Lietuvos Respublikos Aukščiausiosios Tarybos ir Vyriausybès žinios.1990, Nr. 31-755.

19 Lietuvos Respublikos Aukščiausiosios Tarybos (pirmojo šaukimo) antroji sesija. Stenogramos (Nr. 25), supra note 2, p. 441. 
są - ar jie pritaria naujos rengiamos Lietuvos Respublikos Konstitucijos teiginiui: Lietuvos valstybė yra nepriklausoma demokratinè respublika. " Minėtame nutarime nèra nurodyta, kokių teisinių pasekmių turès apklausos rezultatai. Atkreipkime demesị i nutarimo preambulę. Joje rašoma, kad Aukščiausioji Taryba priima ši nutarimą „toliau ịtvirtindama nepriklausomos Lietuvos valstybinguma“. Šis nutarimo preambulès teiginys ypač svarbus, nes jis rodo, kad apklausa rengiama ne dẻl to, kad Aukščiausioji Taryba nutaria atsiklausti tautos, ar Lietuva turi būti nepriklausoma valstybe், - apklausa rengiama ịtvirtinant nepriklausomos Lietuvos valstybingumq. Tai reiškia, kad 1990 m. kovo 11 d. atkurta Lietuvos valstybės nepriklausomybė rengiamos apklausos tvarka negali būti kvestionuojama, kad tautos klausiama nuomonès ne dèl Lietuvos valstybès nepriklausomybès, o tik dèl rengiamos naujos Konstitucijos teiginio „Lietuvos valstybė yra nepriklausoma demokratinè respublika“. Tokia Aukščiausiosios Tarybos $1991 \mathrm{~m}$. sausio $16 \mathrm{~d}$. nutarimo redakcija suteikè galimybę apsaugoti Lietuvos valstybès nepriklausomybę visais atvejais, net ir tuo atveju, jeigu per apklausą nebūtų pritarta teiginiui „Lietuvos valstybè yra nepriklausoma demokratinè respublika“. Vèliau, kai paaiškejjo, jog apklausoje dalyvavo 84,73 proc. visų rinkèjų, o teiginiui „Lietuvos valstybè yra nepriklausoma demokratinè respublika“ pritarė 90,47 proc. visų apklausoje dalyvavusių rinkèjų, tokius apklausos rezultatus buvo būtina panaudoti Lietuvos valstybingumui ittvirtinti. Ir tai buvo padaryta $1991 \mathrm{~m}$. vasario $11 \mathrm{~d}$. prièmus konstitucinị ịstatymą „Dèl Lietuvos valstybès“.

Su teisès mokslinèje literatūroje išdèstytais teiginiais, esą kad visuotinė apklausa (plebiscitas) buvo surengta „siekiant nuostatai dèl Lietuvos valstybės suvereniteto ir valstybès formos suteikti konstitucinị statusą“ ir kad „1991 m. vasario 9 d. plebiscitas, remdamasis tautos suvereniteto principu, galutinai legitimavo $1990 \mathrm{~m}$. kovo $11 \mathrm{~d}$. Nepriklausomybès aktą", negalima sutikti ir dèl to, kad šie teiginiai sudaro klaidingą prielaidą manyti, esą nors iki visuotinès apklausos (plebiscito) nuostata dèl valstybės suvereniteto ir valstybės formos buvo konstatuota Kovo 11-osios Akte ir Laikinajame Pagrindiniame İstatyme ${ }^{20}$, iki šios apklausos (plebiscito) ši nuostata dar neturèjusi konstitucinio statuso (!?). Tai nesuderinama su Kovo 11-osios Akto ${ }^{21}$ nuostata, kad „nuo šiol Lietuva vèl yra nepriklausoma valstybe““; ši Kovo 11-osios Akto nuostata, kaip ir visas Aktas, turi konstitucini statusą nuo jo prièmimo. Nurodytieji teiginiai yra nesuderinami ir su Laikinojo Pagrindinio Istatymo 1 straipsniu, kuriame expressis verbis buvo ịtvirtinta, kad Lietuva yra respublika, kad Lietuva yra suvereni valstybè. Laikinasis Pagrindinis İstatymas buvo ne kas kita, o Laikinoji Konstitucija, taigi nuostata dèl valstybès suvereniteto ir valstybès formos turèjo konstitucinį statusą dar iki $1991 \mathrm{~m}$. vasario $9 \mathrm{~d}$. visuotinès apklausos (plebiscito) ${ }^{22}$.

20 Lietuvos Respublikos Aukščiausiosios Tarybos (pirmojo šaukimo) pirmoji sesija. Stenogramos. Vilnius: Lietuvos Respublikos Aukščiausioji Taryba, 1990, p. 312-335.

21 Ibid., p. 310.

22 Sinkevičius, V. Lietuvos Laisvès Kovos Sąūdžio Tarybos 1949 m. vasario 16 d. Deklaracija Lietuvos teisès sistemoje. Regnum est: 1990 m. Kovo 11-osios Aktui - 20. Liber Amicorum Vytautui Landsbergiui. Vilnius: Mykolo Romerio universitetas, 2010, p. 67-70. 
Teisiškai nekorektišku laikytinas ir teiginys, kad „1991 m. vasario 9 d. plebiscitas, remdamasis tautos suvereniteto principu, galutinai legitimavo $1990 \mathrm{~m}$. kovo 11 d. Nepriklausomybés aktą“. Šiame teiginyje esanti formuluotè "galutinai legitimavo" leidžia daryti ir tokią visiškai klaidingą prielaidą, kad 1990 m. Kovo 11 d. Aktas esą buvo nepakankamai legitimus, nes vèliau plebiscitu buvo „galutinai legitimuotas“ (!?). Teiginys apie 1990 m. Kovo 11-osios Akto tariamai vèliau ịvykusi „galutinị legitimavimą“ yra nesuderinamas su faktu, jog Lietuvos Respublikos Aukščiausioji Taryba-Atkuriamasis Seimas, 1990 m. kovo 11 d. priimdama Aktą dèl nepriklausomos Lietuvos valstybės atkūrimo, turèjo visus tautos suteiktus igaliojimus (mandatą) atkurti nepriklausomą Lietuvos valstybę. Šiuos igaliojimus Aukščiausioji TarybaAtkuriamasis Seimas gavo iš tautos per rinkimus ị šią Aukščiausiąją Tarybą, kurie ivyko 1990 m. vasario 24 d.; teisinis faktas, kad Lietuvos gyventojai, turintys rinkimų teisę, per 1990 m. vasario 24 d. rinkimus suteikè išrinktiems Aukščiausiosios Tarybos deputatams tautos atstovų mandatą ir prievolę atstatyti Lietuvos valstybę ir reikšti tautos suverenią galią per šią Aukščiausiąją Tarybą, yra konstatuotas 1990 m. kovo 11 d. priimtame specialiame Aukščiausiosios Tarybos akte - deklaracijoje „Dèl Lietuvos TSR Aukščiausiosios Tarybos deputatų igaliojimų “23, kuri buvo priimta prieš priimant Aktą dèl nepriklausomos Lietuvos valstybės atkūrimo. Pažymètina, kad 1990 m. Kovo 11 d. Aktu Lietuvos nepriklausoma valstybe buvo atkurta vienkartiniu, neatšaukiamu ir nepaneigiamu tautos atstovų sprendimu, ji buvo atkurta ir legaliai, ir legitimiai, nes Aukščiausiosios Tarybos-Atkuriamojo Seimo deputatai turejo visus tam būtinus tautos jai suteiktus igaliojimus ir garbingai ịvykdè tautos valią. Taigi 1990 m. Kovo 11 d. Akto vèliau nereikejo dar kaip nors „galutinai legitimuoti“24.

$1991 \mathrm{~m}$. vasario $9 \mathrm{~d}$. visuotinė apklausa (plebiscitas) buvo surengta ne tam, kad, kaip rašoma teisès mokslinèje literatūroje, „prieš pradedant rengti būsimos kodifikuotos rašytinès konstitucijos projektą, buvo nuspręsta, jog nuostatą dèl valstybès suvereniteto ir valstybès formos, kuri jau buvo konstatuota Kovo 11-osios akte ir Laikinajame Pagrindiniame İstatyme, reikia ịtvirtinti surengiant visuotinę apklausą - plebiscitą, taip suteikiant šiai normai konstitucinį statusą". Nors taip teigiant yra daromos nuorodos ji Aukščiausiosios Tarybos stenogramas, - taigi lyg ir cituojamos deputatų kalbos, - iš stenogramų matyti, jog Kovo 11-osios Akto nuostatos, kad Lietuvos Respublika yra nepriklausoma demokratinè valstybe், atžvilgiu kaip tik buvo vengiama bet kokių referendumų ar apklausų. Aukščiausiosios Tarybos 1991 m. vasario 11 d. posėdyje Aukščiausiosios Tarybos Pirmininkas V. Landsbergis kalbejo: „<..> iš mūsų štai vis reikalauja kažkokio referendumo, kad pasirodę neapdairūs patys ir pripažintume, jog kovo 11 dienos aktai neva dar nepakankami, ir tada ịkliū-

23 Lietuvos Respublikos Aukščiausiosios Tarybos (pirmojo šaukimo) pirmoji sesija. Stenogramos, supra note 20, p. 308-309.

24 Sinkevičius, V. Lietuvos Laisvès Kovos Sąjūdžio Tarybos 1949 m. vasario 16 d. Deklaracija Lietuvos teisès sistemoje, supra note 22, p. 67-70. 
tume į žinomą „neišstojimo įstatymo“ kilpą. Todèl atsisakydavome, matydami klastą ir primindami, jog rinkejų mums duotas mandatas atkurti nepriklausomybę taip pat yra tautos suverenios galios raiška, kurią mes, išrinkti deputatai, tik paskelbème ir po to vis labiau praktiškai igyvendiname. Bet dabar jau patys nutarème pasitikrinti. $<\ldots>$ Pasitikrinome. Žmonès nėmaž nesuabejoję dèl nepriklausomybės, veikiau priešingai - dar tvirčiau apsisprendę, įsitikinę; jų balsai patvirtino, kad Kovo 11-oji buvo reikalinga ir teisinga, o dabar yra atejęs laikas žengti toliau. ${ }^{\text {“25 }}$

Pabrèžtina, jog rengiant minètą apklausą (plebiscitą) nebuvo net minties, kad gyventojai turès apsispręsti dèl valstybès suvereniteto ar valstybès formos. Kovo 11-osios Akto nuostata, kad Lietuva yra nepriklausoma demokratiné valstybé, nuo pat jo prièmimo buvo ir yra nekvestionuojamas dalykas. Svarbiausias $1991 \mathrm{~m}$. vasario $9 \mathrm{~d}$. visuotinės apklausos (plebiscito) tikslas buvo visiškai kitoks: norèta dar kartą pasaulio valstybių bendrijai parodyti, kad tauta jau pasirinko Lietuvos nepriklausomybę (tautos valią 1990 m. kovo 11 d. Aktu išreiškẻ Aukščiausiosios Tarybos-Atkuriamojo Seimo deputatai); visuotine apklausa (plebiscitu) buvo siekta dar kartą paskatinti užsienio valstybių (taip pat ir Vakarų demokratinių valstybių) vadovus kuo greičiau pripažinti Lietuvos valstybės nepriklausomybę. $1991 \mathrm{~m}$. vasario $11 \mathrm{~d}$. Aukščiausioji Taryba priemė deklaraciją „Dèl Lietuvos Respublikos lygiateisio dalyvavimo pasaulio valstybių bendrijoje“, kuria kreipesi ị visas valstybes, jų parlamentus ir vyriausybes, ragindama atsižvelgti ị $1991 \mathrm{~m}$. vasario 9 d. įvykusio plebiscito rezultatus, ir kviete valstybes paremti Lietuvos laisves ir demokratijos siekius ${ }^{26}$.

\section{Išvados}

1. Lietuvos Respublikos Aukščiausiosios Tarybos 1991 m. vasario 11 d. priimtas konstitucinis ịstatymas „Dèl Lietuvos valstybès“ yra pirmasis konstitucinis įstatymas Lietuvos teises istorijoje, iki tol konstitucinių ịstatymų Lietuvos teisés sistemoje nebuvo.

2. Kol įsigaliojo $1992 \mathrm{~m}$. Konstitucija, konstitucinis įstatymas „Dèl Lietuvos valstybès“ egzistavo kartu su Laikinuoju Pagrindiniu İstatymu (Laikinąja Konstitucija), jo teisinė galia buvo mažesné negu Laikinojo Pagrindinio İstatymo (Laikinosios Konstitucijos).

3. Konstitucinis ịstatymas „Dèl Lietuvos valstybès“ yra ịtrauktas ị $1992 \mathrm{~m}$. Konstituciją kaip jos sudedamoji dalis (Konstitucijos 150 str.), todèl jo teisinè galia yra tokia pati, kaip ir visos Konstitucijos, t. y. jis, kaip ir visos kitos Konstitucijos nuostatos, turi aukščiausią teisinę galią.

25 Lietuvos Respublikos Aukščiausiosios Tarybos (pirmojo šaukimo) antroji sesija. Stenogramos (Nr. 25), supra note 2, p. 441. 
4. Konstitucijoje įtvirtinti ir kitos rūšies konstituciniai įstatymai: vadinami „sąrašiniai“ konstituciniai įstatymai (Konstitucijos 69 str. 3 d.) ir įstatymai, kurie atskiruose Konstitucijos straipsniuose ịvardijami kaip konstituciniai įstatymai (47 str. 3 d.). „Sąrašinių“ konstitucinių ịstatymų ir Konstitucijos 47 str. 3 d. nurodyto konstitucinio isstatymo pagal jų teisinę galią ir keitimo tvarką negalima sutapatinti su Konstitucijos 150 str. nurodytais konstituciniais įstatymais (konstituciniais aktais), nes „sąrašinių“ konstitucinių įstatymų ir Konstitucijos 47 str. 3 d. nurodyto konstitucinio įstatymo teisinė galia yra mažesnè negu Konstitucijos.

5. Nèra teisinio pagrindo sutikti su teisès mokslinèje literatūroje išdèstytais teiginiais, kad visuotinè apklausa (plebiscitas) buvo surengta „siekiant nuostatai dèl Lietuvos valstybės suvereniteto ir valstybès formos suteikti konstitucinị statusą" ir kad „1991 m. vasario 9 d. plebiscitas, remdamasis tautos suvereniteto principu, galutinai legitimavo 1990 m. kovo 11 d. Nepriklausomybès aktą“. Nuostata dèl Lietuvos valstybès suvereniteto ir valstybès formos turèjo konstitucinị statusą pagal $1990 \mathrm{~m}$. Kovo 11-osios Aktą ir Laikinąji Pagrindinị Istatymą (Laikinąją Konstituciją).

\section{Literatūra}

Deklaracija „Dèl Lietuvos TSR Aukščiausiosios Tarybos deputaty igaliojimu“". Lietuvos Respublikos Aukščiausiosios Tarybos (pirmojo šaukimo) pirmoji sesija. Stenogramos. Vilnius: Lietuvos Respublikos Aukščiausioji Taryba, 1990.

Lietuvos Respublikos Aukščiausiosios Tarybos Aktas „Dèl Lietuvos nepriklausomos valstybès atstatymo“. Lietuvos Respublikos Aukščiausiosios Tarybos (pirmojo šaukimo) pirmoji sesija. Stenogramos. Vilnius: Lietuvos Respublikos Aukščiausioji Taryba, 1990.

Lietuvos Respublikos Aukščiausiosios Tarybos deklaracija „Dèl Lietuvos Respublikos lygiateisio dalyvavimo pasaulio valstybiu bendrijoje“. Lietuvos Respublikos Aukščiausiosios Tarybos (pirmojo šaukimo) antroji sesija. Stenogramos (Nr. 25). Vilnius: Lietuvos Respublikos Seimo leidykla,1993.
Lietuvos Respublikos Konstitucija. Lietuvos Respublikos Aukščiausiosios Tarybos ir Vyriausybès žinios. 1992, Nr. 33-1014.

Lietuvos Respublikos Laikinasis Pagrindinis Istatymas. Lietuvos Respublikos Aukščiausiosios Tarybos (pirmojo šaukimo) pirmoji sesija. Stenogramos. Vilnius: Lietuvos Respublikos Aukščiausioji Taryba, 1990.

Sinkevičius, V. Konstitucinių įstatymų samprata: teoriniai aspektai. Jurisprudencija. 2008, Nr. 2(104).

Sinkevičius, V. Lietuvos Laisvès Kovos Sąūdžio Tarybos 1949 m. vasario 16 d. Deklaracija Lietuvos teisès sistemoje. Regnum est: 1990 m. Kovo 11-osios Aktui - 20. Liber Amicorum Vytautui Landsbergiui. Vilnius: Mykolo Romerio universitetas, 2010.

Vaičaitis, V. Konstituciniu istatymu fenomenas. Vilnius: Teisinès informacijos centras, 2004. 
Žilys, J. Iš konstitucionalizmo istorijos.1991 m. vasario $9 \mathrm{~d}$. apklausa (plebiscitas) Lietuvos konstitucionalizmo požiūriu. Justitia. 2001, Nr. 1(31).

Anotacija. $1991 \mathrm{~m}$. vasario $11 \mathrm{~d}$. priimtas konstitucinis įstatymas „Dèl Lietuvos valstybès" yra pirmasis konstitucinis įstatymas Lietuvos teisés istorijoje. Straipsnyje atskleidžiamos jo priemimo aplinkybès, parodomas ryšys su $1991 \mathrm{~m}$. vasario 9 d. jvykusia gyventojų visuotine apklausa (plebiscitu). Nagrinejama, kuo šis konstitucinis įstatymas skiriasi nuo šiuo metu galiojančioje Konstitucijoje ịtvirtinto konstituciniu ịstatymu instituto. Pateikiami argumentai, paneigiantys teisès mokslinèje literatūroje išdèstyta nuomone, kad visuotine apklausa (plebiscitas) buvo surengta „siekiant nuostatai dèl Lietuvos valstybès suvereniteto ir valstybès formos suteikti konstitucini statusq“. Straipsnyje remiamasi ne tik tuo metu galiojusiu Laikinuoju Pagrindiniu Istatymu ir kitais teisès aktais, bet ir autentiška, dar niekur neskelbta $1991 \mathrm{~m}$. vasario $11 \mathrm{~d}$. priimto Konstitucinio įstatymo projekto rengimo medžiaga.

Reikšminiai žodžiai: pirmasis konstitucinis įstatymas, visuotine apklausa (plebiscitas), Laikinasis Pagrindinis Istatymas (Laikinoji Konstitucija), 1992 m. Konstitucijoje numatytas konstituciniu istatymu institutas.

\title{
THE FIRST CONSTITUTIONAL LAW IN LITHUANIA: HOW DID IT COME INTO BEING?
}

\author{
Vytautas Sinkevičius \\ Mykolas Romeris University, Lithuania
}

Summary. The Constitutional Law "On the State of Lithuania" that was adopted on 11 February, 1991 is the first constitutional law in the history of Lithuania's law. The author describes the circumstances in which this constitutional law was adopted and discloses the relation of this law to the general poll (plebiscite) held on 9 February, 1991. The article shows how this constitutional law is different from the institute of constitutional laws established in the Constitution that is in force at present. The Constitutional Law "On the State of Lithuania" has been included into the Constitution of 1992 as its constituent part (Article 150 of the Constitution), therefore, its legal power is the same as that of the entire Constitution, i.e., the constitutional law in question has the supreme legal power as the rest provisions of the Constitution do. The Constitution also consolidates constitutional laws of a different type, i.e., the constitutional laws that must be included into the list of constitutional laws (Paragraph 3 of Article 69 of 
the Constitution), as well as the laws that are referred to as the constitutional ones in separate articles of the Constitution (Paragraph 3 of Article 47 of the Constitution). One is not allowed to identify the constitutional laws included into the list of constitutional laws and the constitutional law specified in Paragraph 3 of Article 47 of the Constitution, on the one hand, with the constitutional laws (constitutional acts) specified in Article 150 of the Constitution, on the other hand, since the legal power of the constitutional laws included into the list of constitutional laws and the constitutional law specified in Paragraph 3 of Article 47 of the Constitution is lower than the legal power of the Constitution. The arguments of the article are critical of the opinion found in the scientific legal literature that the general poll (plebiscite) was held "in order to grant the constitutional status to the provision regarding the sovereignty and form of the State of Lithuania".

Keywords: the first constitutional law, a general poll (plebiscite), the Provisional Basic Law (Provisional Constitution), the institute of constitutional laws provided for in the Constitution of 1992.

Vytautas Sinkevičius, Mykolo Romerio universiteto Teisès fakulteto Konstitucinès ir administracinès teisés instituto profesorius. Mokslinių tyrimų kryptys: konstitucija, konstitucijos interpretavimas, konstitucinė priežiūra, parlamento veiklos teisinis reguliavimas.

Vytautas Sinkevičius, Mykolas Romeris University, Faculty of Law, Department of Constitutional and Administrative Law, Professor. Fields of scientific research: the Constitution, interpretation of the Constitution, constitutional review, the legal regulation governing the activity of the parliament. 